\title{
Carbon Credit Risk Mitigation of Deforestation: A Study on the Performance of P2H Products and Services in Indonesia
}

\author{
Wiwik Utami ${ }^{1}$, Lucky Nugroho ${ }^{1} \&$ Kelum Jayasinghe ${ }^{2}$ \\ ${ }^{1}$ Universitas Mercu Buana, Jakarta, Indonesia \\ ${ }^{2}$ Essex Business School (EBS), University of Essex, UK \\ Correspondence: Lucky Nugroho, Universitas Mercu Buana, Jakarta, Indonesia. E-mail: \\ lucky.nugroho@mercubuana.ac.id
}

Received: October 10, 2020

Accepted: December 24, 2020

Online Published: January 11, 2021

doi:10.5430/ijfr.v12n2p125

URL: https://doi.org/10.5430/ijfr.v12n2p125

\begin{abstract}
This study aims to analyze the performance of the loan products and services offered by Indonesian government's Forest Development Financing Center (BLU-P2H Center) that target the prevention and repair of forest damage. The methodology used is a systematic literature review that identifies, assesses, and interprets this chosen research topic's findings. The study attempts to answer three formulated research questions - (i) How can P2H products and services policies that align with the carbon credit risk mitigation of deforestation be mapped?; (ii) How should $\mathrm{P} 2 \mathrm{H}$ products and services that contribute to carbon credit risk mitigation be investigated?; and (iii) How can the impact of P2H products and services in preventing deforestation be measured? The systematic literature review findings highlight that the Indonesian Government has adopted some important provisions and institutions, namely P2H products and services, and carried out loan disbursements to prevent forest destruction, specifically, the forestry business and environmental investment financing. The findings also indicate that while the government most extensively disbursed certain loans, such as community forest enterprises (HR), there was a low level of loan disbursement for community forest-based loans $(\mathrm{HKm})$ because of the constraints faced by farmers in arable land that produces seasonal crops. Therefore, the study implicates that the forest destruction, particularly in Indonesia, resulting from illegal logging by local communities, needs to be further prevented by increasing the public knowledge on the sustainability impact of deforestation and also by increasing the public's access to and opportunities for public welfare, alternative livelihoods, and micro-business activities. The study findings also make an original contribution to the literature on the carbon credit risk mitigation of forest damage as they illustrate a government-sponsored, innovative $\mathrm{P} 2 \mathrm{H}$ scheme in the form of loan disbursement aiming to reduce and prevent forest destruction.
\end{abstract}

Keywords: carbon credit, risk mitigation, deforestation, legitimacy, $\mathrm{P} 2 \mathrm{H}$ products

\section{Introduction}

Recent climate change has increasingly harmed human life in all countries of the world. Therefore, efforts to prevent environmental damage are the responsibility of all stakeholders in the world (Elkinjton, 1998; Slaper \& Hall, 2011). The entire world is currently experiencing the disastrous impact of climate change - global warming. Therefore, global institutions such as the UN have launched worldwide programs and activities under the Sustainable Development Goals (SDGs) for its member countries (Arruda Filho et al., 2019; Scheyvens et al., 2016). The issue of sustainability has now become a common issue for the world community because sustainability requires that all stakeholders carry out their business and other livelihood activities for the long term by balancing economic, social, and environmental interests (Alt et al., 2015; Arafah et al., 2018; Galbreath \& Shum, 2012; Nugroho et al., 2017; Wolf, 2014).

Therefore, sustainability requires world leaders' focus on mitigating and preventing environmental damage as a climate change source (Kelman, 2017; Major et al., 2018). Furthermore, forests act as a counterweight to clean air because forests are one of the biosphere ecosystems with relatively dominant plant composition (Meijaard et al., 2013; Sapkota et al., 2005), thereby serving as one of the most dominant ecosystems in consuming CO2 (carbon dioxide) and making an essential contribution to nature as a CO2 absorber (Ciais et al., 2013; Goulden et al., 2004; Tupan \& Lailossa, 2019). Indonesia, a tropical country, has become a global concern, mostly because of its ownership of the ninth-largest forest land in the entire world and its ranking of having the third largest area of 
tropical forest after Brazil and Zaire (Barlow \& Peres, 2004; Fuller, 2006; Ginoga et al., 2005; Nugroho et al., 2020). Furthermore, according to Alam et al. (2016) and Carlson et al. (2012), Indonesia has been recorded as $10^{\text {th }}$ largest in terms of contributing to the world's environmentally hazardous carbon emissions (see Table 1 and Figure 1).

Table 1. Top 10 polluter countries

\begin{tabular}{llrr}
\hline Rank & Countries & $\begin{array}{l}\text { 2018 carbon dioxide emissions } \\
\text { (in billions of tons) }\end{array}$ & $\begin{array}{l}\text { World share } \\
\text { (in percent) }\end{array}$ \\
\hline 1 & China & 10.06 & 28 \\
\hline 2 & United States & 5.41 & 15 \\
\hline 3 & India & 2.65 & 8 \\
\hline 4 & Russia & 1.71 & 5 \\
\hline 5 & Japan & 1.16 & 3 \\
\hline 6 & Germany & 0.75 & 2 \\
\hline 7 & Iran & 0.72 & 2 \\
\hline 8 & South Korea & 0.65 & 2 \\
\hline 9 & Saudi Arabia & 0.62 & 2 \\
\hline 10 & Indonesia & 0.61 & 2 \\
\hline
\end{tabular}

Source: Alam et al., 2016 and Carlson et al., 2012)

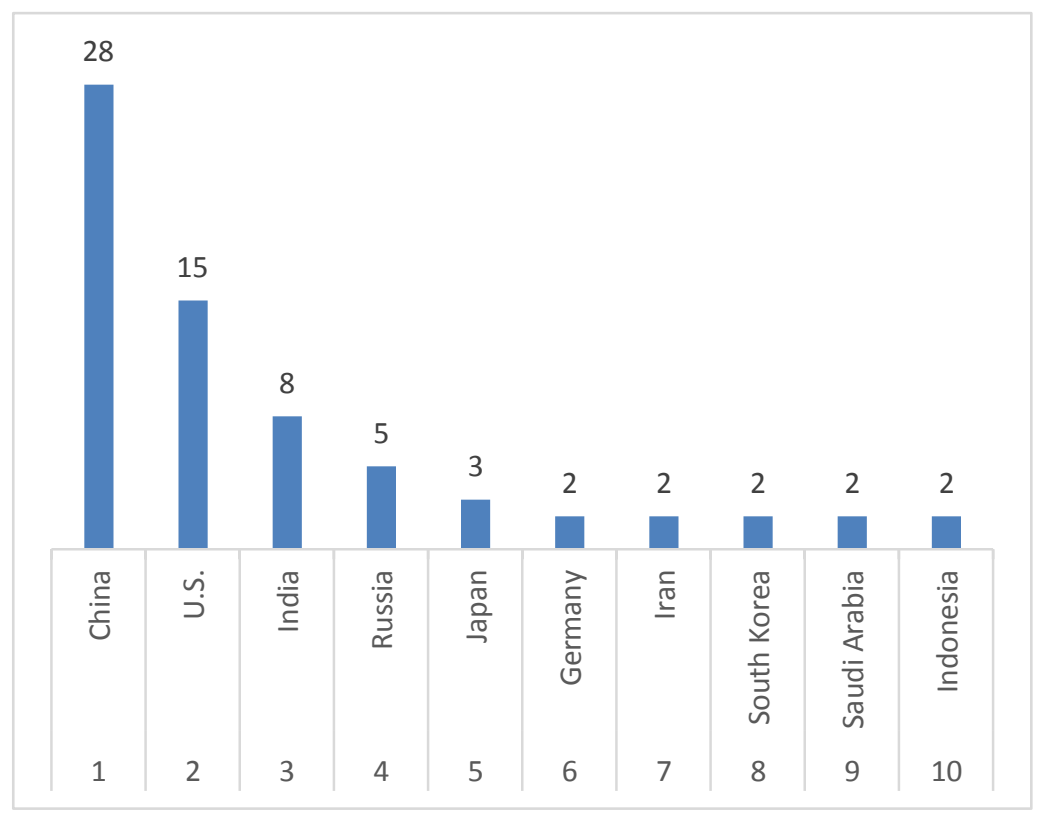

Figure 1. Percentage of carbon dioxide contributor countries

Source: Alam et al., 2016 and Carlson et al., 2012

More specifically, Indonesia, together with the other industrial countries in the world, such as China, the U.S., India, Russia, Japan, Germany, South Korea, and Saudi Arabia, contributes significantly to air pollution. Therefore, world leaders have recognized the need to prevent and mitigate environmental damage, especially in Indonesia's forests, referred to as "the world's lungs" by some scholars (Baransano \& Mangimbulude, 2011). For instance, Indonesia is included in the 10 countries with the highest tropical rain forest loss in 2018. In that year, Indonesia lost 339,888 
hectares (ha) of primary tropical rain forest land and ranked as having the third-worst loss of such land after Brazil (1.35 million ha) and Congo (481,248 ha) (Kusnandar \& Widowati, 2019). According to Ardhana (2010) and Majid et al. (2016), the damage to tropical rainforests has been caused by several things, including (i) the expansion of mining activities; (ii) forest fires; and (iii) the conversion of forest land for settlement, agriculture, and plantations. These three factors are thus identified as the main drivers of deforestation in the world, including Indonesia.

In this sense, there is widespread pressure on the Indonesian Government, as one of the stakeholders legitimately responsible for environmental sustainability, to implement programs and activities related to ecological conservation improvement and damage mitigation. For instance, under the Ministry of Environment and Forestry, the Indonesian Government has established specialist institutions, such as the Forest Development Financing Center (P2H Center), to achieve this purpose. The primary function of the $\mathrm{P} 2 \mathrm{H}$ Center is to provide financial/capital support for forestry businesses and environmental investment to prevent and repair forest damage in Indonesia (Alviya et al., 2020). These forest damage prevention and repair programs aim to improve air quality and reduce pollution's impacts. Against this background, this study conducts a systematic review (Onwuegbuzie \& Frels, 2015; Suri et al., 2006) of the government's P2H Center's published documents explaining its programs implemented for the prevention and repair of forest damage and answers the following formulated research questions: (i) How can P2H policies that align with the carbon credit risk mitigation of deforestation be mapped?; (ii) How should $\mathrm{P} 2 \mathrm{H}$ products that contribute to carbon credit risk mitigation be investigated?; and (iii) How can the impact of $\mathrm{P} 2 \mathrm{H}$ in preventing deforestation be measured? By doing so, the study aims to examine the role of government in forest sustainability from the credit carbon perspective, in particular, establishing the policies aligned with the carbon credit risk mitigation of deforestation activities, investigating the $\mathrm{P} 2 \mathrm{H}$ products that can mitigate deforestation, and measuring the performance of $\mathrm{P} 2 \mathrm{H}$ products in regard to deforestation. This study's novelty is that there has been no prior research related to mitigating the risk of forest damage in terms of the governmental distribution of loans aiming to reduce and prevent forest destruction, particularly in Indonesia.

\section{Literature Review}

National economic development programs aim to provide welfare to a country's people and adopt policy instruments to achieve it (Helmsing, 2003; Polozhentseva \& Klevtsova, 2015). Such programs' policy documents include guidelines for implementation and application and contain certain restrictions that ensure the development process can be directed under mutually determined goals (Stupak et al., 2007; Welford et al., 1999). Furthermore, to achieve the development objectives, the policies that have been compiled and made must be implemented and applied correctly (Eaton \& Kostka, 2014). Therefore, for the effective implementation of policy, it is necessary to determine and measure the programs that can have a genuine impact or have implications for improving the welfare of the community and analyze the results following the expectations of the compilers and stakeholders who have an interest in the existence of the policy (Eaton \& Kostka, 2014; Sovacool, Linnér, \& Klein, 2017). Alternatively, the proper application of guidelines in the form of planned and systematic activities, projects, and programs based on norms and provisions to achieve specific goals that have become joint commitments is required for effective policy implementation (Nugroho et al., 2019; Utami et al., Weintraum, 1983).

Furthermore, policy implementation requires compliance as a condition of success so that its outcomes can be matched with the stakeholders' expectations (Barkemeyer, 2009). Therefore, for the successful implementation of policies, the implementers' legitimacy is also necessary (Nivette \& Akoensi, 2019). Nivette and Akoensi (2019) state that legitimacy is the power to rule such that the policy's implementer becomes obedient to the regulatory makers and stakeholders and makes the right decisions and follows the policies that have been set. According to Nivette and Akoensi (2019), legislation is necessary to enforce the provisions if there is no compliance from the implementer in implementing the policy; that is, there will be sanctions or fines under the applicable rules. According to Scott (2009) and Skogstad (2003), the party with the primary and ultimate authority to govern the implementation of policies is the government in power. Therefore, it is argued that the implementation of policies related to forest destruction prevention requires vigorous law enforcement and heavy sanctions by the government at the implementation level.

The current issues concerning increased sustainability, economic growth, and business activities require more emphasis on all stakeholders' social aspects and environmental sustainability rather than on mere profit-orientation (Nilsen, 2019). Therefore, current business growth must be aligned with the long-term objectives of business and society, particularly around the recent circular economy concept. Thus, the circular economy concept aims to maintain the optimal quality of products, outputs, materials, and components in the business process (see Figure 2). 


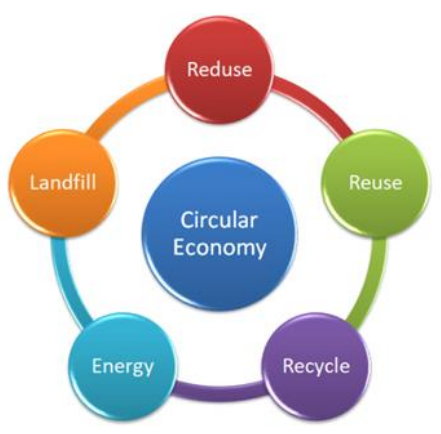

Figure 2. The crucial elements in the circular economy

Source: Nilsen, 2019

As demonstrated in Figure 2, the circular economy includes the following crucial elements: (i) reduce the use of raw materials and energy, the pressure on nature, and waste; (ii) reuse waste that can still be used for the same function or other functions; (iii) recycle materials, reprocessing (recycling) waste into new useful goods or products; (iv) incinerate waste with heat recovery; and (v) conduct the waste management (eradication)/landfill system in an effective manner and without damaging the environment. According to Millward-hopkins and Purnell (2019) and Pieroni et al. (2019), the definition of a circular economy includes, among others, the implementation of the following policies: (i) reuse, repair, and recycle; (ii) implement a policy of green space and land that is environmentally friendly and supports sustainable innovation; and (iii) implement policies to increase the market for used goods that can be reused and the use of secondary materials. Therefore, the activities related to preventing deforestation and reducing air pollution through the reforestation measures taken by the Indonesian Government can be classified as elements of the circular economy.

According to the literature, one contributor to environmental damage is the local-level micro- and small-scale business sector actors (Nugroho et al., 2017). These actors engage with certain business activities that damage the environment, such as deforestation, with the economic motivation of fulfilling basic livelihood needs. These people, including those who live around the forest, have limited knowledge on and interest in environmental sustainability. They are more concerned with survival and prosperity in their economic lives. For instance, Indonesia's forest destruction perpetrators are the people who open agricultural land for their basic economic needs by burning forests (Mustofa, 2011). They cause forest destruction because of their insufficient knowledge and understanding of the importance of forest sustainability (Maryati, 2011). Also, the theft of wood causes damage to the forest. Timber theft in forests in Indonesia is carried out by people living around these forests whose aim is to sell them to wood collectors to meet their basic economic needs (Damayatanti, 2011).

Because of these continuous environmentally damaging activities, the Indonesian Government has tried to channel finances by establishing microfinance institutions such as cooperatives in the village communities living around the forest as an alternative livelihood promotion method and means of improving their welfare. People receive the capital to create alternative businesses away from the forest to fulfill their families' economic needs (Beisland \& Mersland, 2012; Hudon, 2013; Postelnicu \& Hermes, 2018). Therefore, previous studies and Indonesia's experience suggest that government intervention is needed to prevent the environmental damage done by communities living around the forest. Extending this knowledge in the literature, the present study attempts to analyze the Indonesian Government's policies and measurements aligned with the carbon credit risk mitigation activities of deforestation, particularly the products and services implemented by the P2H Center.

\section{Research Method}

To analyze the Indonesian Government's P2H products and services to prevent and repair forest damage, the study uses a systematic literature review approach. According to the methodology literature, a systematic literature review identifies, assesses, and interprets all findings on a research topic to answer the formulated research questions (Greene, 2006; Onwuegbuzie \& Frels, 2015). Accordingly, the current study address the following three interrelated research questions identified from the initial literature review and problematization: (i) How can $\mathrm{P} 2 \mathrm{H}$ policies that align with the carbon credit risk mitigation of deforestation be mapped?; (ii) How should $\mathrm{P} 2 \mathrm{H}$ products that contribute to carbon credit risk mitigation be investigated?; and (iii) How can the impact of $\mathrm{P} 2 \mathrm{H}$ in preventing deforestation be measured? The study's meta-analytical framework has involved a three-phase systematic review 
process, namely (i) exploration, (ii) interpretation, and (iii) communication. Here, the exploration phase was more crucial and included the following five additional steps (Onwuegbuzie \& Frels, 2015): (i) exploring beliefs and topics, (ii) initiating the search, (iii) storing and organizing information, (iv) selecting/deselecting information, and (v) expanding the search to include one or more MODES (media, observation[s], documents, expert[s], secondary data). Conceptually, this three-phase (seven-step) model provides a cyclical process. It returns to the exploration phase again, even after the communication phase, depending on the follow-up or further questions identified from the systematic literature review's initial cycle.

Applying the three-phase (seven-step) model (Onwuegbuzie \& Frels, 2015), the current study identified the following two central topics: (i) $\mathrm{P} 2 \mathrm{H}$ policies and (ii) measurements adopted by the Indonesian Government. The study's initial search involved the primary P2H documents published by the P2H Center (P2H Center, 2015, 2018). The information in these documents helped the researchers to select and deselect and map the $\mathrm{P} 2 \mathrm{H}$ policies and investigate the $\mathrm{P} 2 \mathrm{H}$ products that can contribute to both the risk and mitigation of deforestation. In the next step, the researchers used the MODES and analyzed media reports, detailed documents by other agencies (Hadi, 2017; Leonard, 2019), and expert opinions (e.g., Mando et al., 2020; Safitri, Roessali, \& Ekowati, 2019) as well as all the forms of reports containing secondary data that helped to measure the impact of $\mathrm{P} 2 \mathrm{H}$ products in stopping deforestation (e.g., P2H Center, 2019a, 2019b, 2019c). The main findings generated from this first phase (five-step approach) of the systematic literature review are interpreted (phase 2) and communicated (phase 3) in the next section.

\section{Findings and Discussion}

\subsection{The Policies Aligned With the Carbon Credit Risk Mitigation of Deforestation}

The carbon credit risk mitigation of deforestation in Indonesia is shaped by various regulatory and policy measures set up by the government. For instance, the Ministry of Forestry issued Forestry Minister Regulation Number P.31/Menhut-II/2007 on August 7, 2007. Article 27 states that the Forest Development Financing Center (P2H Center) is the Forest Development Financing Agency, referred to in the Minister of Finance Decree No. 137/KMK.05/2007. Furthermore, the Finance Minister appointed the P2H Center as a Government Agency Implementing the Financial Management Pattern for Public Service Bodies in Full based on Decree Number: 105/KMK.05/2010, dated March 9, 2010.

Moreover, the Forest Development Financing Center's (P2H) vision and mission are stated as follows: "To become a professional and trusted financial center to support forestry businesses and environmental investment" (P2H Center, 2020b). Moreover, the mission of the P2H Center is documented as follows: (i) Building a financing network for forestry and environmental investment businesses, especially the forestry small- and medium-scale revolving fund facility (FDB); (ii) Realizing excellent service in forestry business financing and environmental investment supported by a reliable organization, professional human resources, adequate infrastructure, and accountable financial management (P2H Center, 2020b). Based on the Regulation of the Minister of Environment and Forestry Number P.18/MENLHK-II/2015 concerning the Ministry of Environment and Forestry's Organization and Work Procedure, the main duties and functions of the $\mathrm{P} 2 \mathrm{H}$ Center are "Implementing financial management as well as channeling and returning revolving funds to finance plantation forest development" (P2H Center, 2020a). The functions of $\mathrm{P} 2 \mathrm{H}$ include (i) the formulation of technical policies, plans, programs, and activities for managing revolving funds to finance plantation forest development and environmental investment; (ii) implementing technical policies for revolving fund management to finance plantation forest development and environmental investment; (iii) the analysis of the feasibility of revolving fund financing, engagement, and risk control for revolving fund financing; and (iv) the implementation of central administrative and household affairs.

The P2H Center manages the Indonesian government's revolving funds allocated for the financing of forestry businesses and environmental investment. The funding for the forestry business financing comes from the government's specially formed Reforestation Fund, which is placed under the Ministry of Finance, international funds and other legal sources and funds. On November 8, 2004, the Ministry of Finance on behalf of Government of Indonesia has signed the refund of the Debt for Nature Swap (DNS) program under the Separate Arrangement Agreement with the Government of Germany to obtain the international funding for P2P Center activities. This was an amendment to the to the original Consolidation Agreement signed between the countries on October 2, 2002, concerning Debt Swap III for the Nature.

Thus, the Indonesian Government has a policy through the provisions issued by the Ministry of Environment and Forestry Number P.18/MENLHK-II/2015 Chapter XVIII appointing P2H as an institution fostered by the Director-General of Sustainable Production Forest Management, the Director General of Social Forestry and 
Environmental Partnership, and the Director-General of Pollution and Environmental Damage Control. The P2H Center's function is to carry out the financial management and distribution and return of revolving funds to finance plantation forest development. However, the study's analysis and interpretation of these policies indicate that government regulations should be upgraded to the level of strict laws so that they have more substantial legitimacy and give the power to government agencies, such as the P2H Center, to maintain the internationally recommended sustainability standards against deforestation (Sanudin et al., 2015). For instance, the position of the P2H Center should not be under the ministry but should be a body placed at the same level as the ministry. Thus, if the P2H Center were to become a ministry-level agency, the programs and policies for mitigating forest damage could be executed better, and it could spread its carbon credit risk mitigation activities equally over all the regions of Indonesia. Given the level of forest destruction in Indonesia, it can be argued that the situation is alarming and that such an initiative is quite valuable.

\subsection{The P2H Products Targeting the Carbon Credit Risk Mitigation of Deforestation}

The P2H Central Service is a revolving fund facility financing business actors in forestry and environmental investment (P2H Center, 2019b). The two forms of financing offered by the P2H Center are (i) forestry business financing and (ii) environmental investment financing. Firstly, in the forestry business financing, the P2H Center distributes funds in loan schemes, profit-sharing schemes, and sharia contracts. The distribution pattern can be made through an intermediary agency or without an intermediary institution (direct). The types of forestry businesses that can be financed through this revolving fund facility include the following:

- Industrial plantation forest business (HTI);

- Community plantation forest business (HTR);

- Community forest enterprises (HR);

- Village forest enterprises (HD);

- Community forestry business (HKm);

- Non-timber forest product (HHBK) utilization businesses;

- Natural forest utilization business with silvicultural enrichment techniques (NFU); and

- Ecosystem restoration (RE).

The forestry business includes forestry businesses that are either on-farm or off-farm. The targets for granting the revolving fund facility first include the forestry business actors in the context of RHL activities, consisting of HTI business actors, HTR business actors, HR business actors, HD business actors, HKm business actors, HHBK business actors, Silin actors, and RE actors and, second, the state-owned enterprises that have been assigned or delegated authority to manage state forests (P2H Center, 2019b).

Secondly, the environmental investment financing of the $\mathrm{P} 2 \mathrm{H}$ Center is provided in the form of a loan scheme. The distribution is carried out through an intermediary institution with an executing and channeling pattern. The investment criteria that can be financed include waste treatment, 3R (reduce, reuse, recycle), more environmentally friendly replacement, the efficiency of production and natural resources, and emissions reduction. Environmental investment financing facilities are provided primarily to micro-, small-, and medium-scale businesses, both individuals and business entities. The benefits for the community and donors in the program are as follows ( $\mathrm{P} 2 \mathrm{H}$ Center, 2019a, 2019c, 2019b):

- Community income is increased through compensation for environmental funds without having to cut trees and/or damage the environment;

- Compensation funds distributed in the environment are obtained more easily and quickly;

- Communities receiving environmental funds can receive assistance from appointing institutions so that the sustainability of the environmental protection program can be maintained;

- Donor countries/institutions can directly interact with the P2H Center as the coordinator of environmental fund management in terms of providing grant funds for environmental protection programs;

- The direct supervision of the distribution of environmental funds can be conducted through appointing a custodian bank as the trustee.

\subsection{The Performance of $22 H$ Products and Services}

One of this study's objectives is to analyze the usefulness of loan products distributed by the $\mathrm{P} 2 \mathrm{H}$ Center. The 
statistics published by the $\mathrm{P} 2 \mathrm{H}$ Center (P2H Center, 2015, 2018) illustrate the following amounts of distribution for forestry businesses in Indonesia (see Table 2 and Figure 3):

Table 2. Financing Purposes amount as of September 2018

\begin{tabular}{lc}
\multicolumn{1}{c}{ Financing Purposes } & Amount (RP) \\
\hline HR—Community forest enterprises & $447,839,796,998$ \\
\hline HTI—Industrial plantation forest businesses & $101,683,682,622$ \\
\hline HHBK—Non-timber forest product utilization businesses & $61,984,496,200$ \\
\hline HD—Village forest enterprises & $33,028,977,787$ \\
\hline HTR —Community plantation forest businesses & $21,189,781,307$ \\
\hline HKm—Community forestry businesses & $8,847,382,199$ \\
\hline $\begin{array}{l}\text { NFU \& RE—Natural forest utilization business with } \\
\text { silvicultural enrichment techniques \& ecosystem restoration }\end{array}$ & $2,357,850,000$ \\
\hline \multicolumn{2}{c}{ Total } \\
\hline
\end{tabular}

Source: P2H Center, 2018

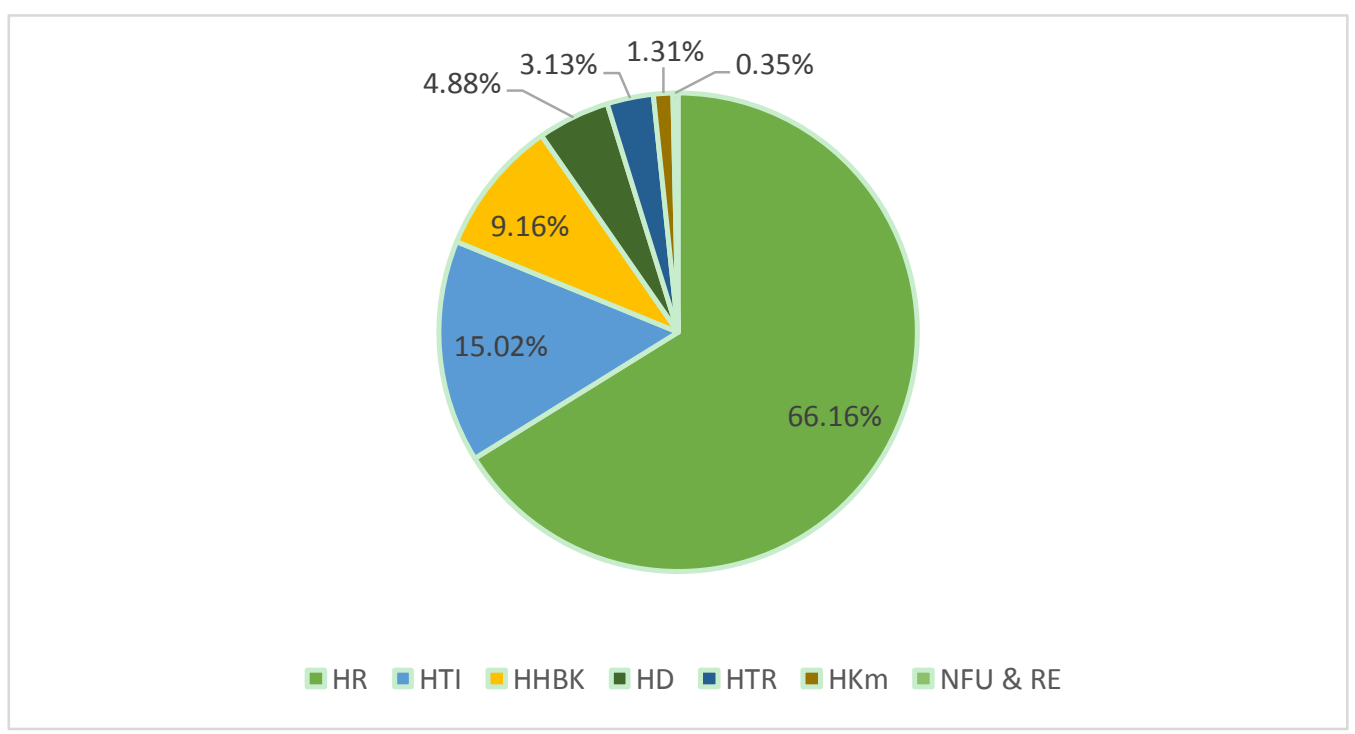

Figure 3. The portion of credit carbon products

Source: P2H Center, 2018

Accordingly, the distribution of community forest financing (HR) occupies the first level of financial or credit products from $\mathrm{P} 2 \mathrm{H}$ distributed to the community. The delivery of community forest financing is the provision of loans to forest farmers. Community forest farmers obtain this loan by providing collateral for their trees to the $\mathrm{P} 2 \mathrm{H}$ Center. This is a form of appreciation from the government for farmers planting the trees as oxygen producers by providing soft credit called delayed logging (Leonard, 2019). Each farmer who is part of the forestry business unit earns a maximum of IDR 200 million. The borrowing period (HR) is up to crop harvesting or a maximum of eight years. The loan interest charged to the community forest farmers who receive these loans is established as $6.5 \%$ per year, representing a lower rate than the people's business credit (KUR) - micro-business credit subsidized by the government. Loan recipients must use this revolving fund loan specifically for the loan's purpose, namely, productive economic activities. The community forest farmers can also meet their urgent needs, including their daily needs. Suppose the loan customer has to harvest plants before the end of the loan period, for example, due to pests. In that case, he/she is obliged to report this to the $\mathrm{P} 2 \mathrm{H}$ Center, and that is followed by an obligation to return the loan 
no later than 30 days after the harvesting of the plants is carried out. The purpose of the delayed felling loan (HR) is to support efforts to postpone the felling of trees' to achieve the maturity of cutting to obtain optimal tree economic value. Furthermore, the funds provided can support productive economic activities to help improve the welfare of forest farmers. Several productive businesses can be options for forest farmers utilizing HR loans, including livestock, agricultural business capital, opening a shop or grocery store, party equipment for rental business parties, and rural transportation business (B. Nugroho, 2010).

Industrial plantation forest (HTI) financing that is expected to rehabilitate the damaged and no longer productive forest areas is in the second position in the distribution list. The main objective of HTI financing is to support the development of the domestic forest products industry to increase added value and foreign exchange, increase land productivity and environmental quality, and expand employment and business fields for the community (Hakim, 2009). Thus, the distribution of HTI financing is aimed at business entities or business actors to obtain capital to increase their capital to run their operations to grow the industrial plants to rehabilitate damaged and no longer productive forests. It can also be interpreted that these businesses' existence can create employment opportunities for the people living in the forest area.

Activity to provide financing to forestry businesses, both on-farm and off-farm, has the principle of supporting the empowerment of the people's economy, which aims to alleviate poverty, expand employment opportunities, and increase forest productivity to improve environmental quality (Raharjo, 2019). Specifically, the off-farm forestry businesses that can be financed by the $\mathrm{P} 2 \mathrm{H}$ Center are forest product processing businesses such as sawmills and/or wood preservation with a variety of products, including sawn timber and then wood panels with various products, including veneer, plywood, laminated veneer lumber (LVL), plywood faced bamboo, bare core, blockboard, particleboard, and fiberboard. Another business is wood chips with various products and wood-based bioenergy with various products, including wood pellets, wood charcoal, biofuel, and biogas.

In most documents, community forest (HR) and community plantation forest (HTR) appear to represent the same meaning. Still, HR and HTR have some practical differences in their status as HR is the forest managed by the community, and its status is outside the forest area. In contrast, HTR is in a productive forest area (Donny, 2017), and its credit distribution occupies the fourth position in the credit disbursement list of the P2H Center, aiming to prevent forest damage and undertake forest repairs.

Finally, the community forest-based loans $(\mathrm{HKm})$ from the P2H Center offer credit for preventing forest destruction. It is hoped from this loan scheme that the local community's welfare can be increased through the optimal, fair, and sustainable use of forest resources while maintaining the preservation of forest and environmental functions. However, the previous studies report a low level of loan disbursement for HKm products due to some constraints (Nandini, 2013). These constraints include the area of arable land that does not match the number of participants living in this area. The farming system in this area is still simple and subsistence in nature, and so the possibility of community self-help is relatively small. Because of these practicalities, the results are not acceptable and satisfactory from this type of farming, and these farmers tend to produce only seasonal crops. Ultimately, these farmers cannot obtain the required guarantees, namely legal and business certainty for the community forest-based loans (HKm). However, the study's analysis indicates that the government and P2H management still have not paid enough attention to the farmers who generate small added value from their input, post-harvest, and marketing.

\section{Conclusion}

The study aimed to investigate the policies and products in the carbon credit risk mitigation of deforestation in Indonesia. Using a systematic literature review approach (Onwuegbuzie \& Frels, 2015; Suri et al., 2006), it attempted to answer the questions of how to map $\mathrm{P} 2 \mathrm{H}$ policies that align with the carbon credit risk mitigation of deforestation and investigate which $\mathrm{P} 2 \mathrm{H}$ products effectively contribute to the carbon credit risk mitigation of deforestation. The study also investigated the performance of $\mathrm{P} 2 \mathrm{H}$ products in terms of preventing deforestation. The overall findings of the study indicate and confirm the Indonesian Government's crucial regulatory and governing role in preventing forest destruction. The study thus provided a detailed analysis of the Indonesian Government's policy initiatives and programs to mitigate the risk of forest destruction and repair forest damage.

Its systematic literature review revealed that the Indonesian Government, through its $\mathrm{P} 2 \mathrm{H}$ program, has established many carbon credit risk mitigation policies that support forest sustainability at the national and regional levels. The carbon credit risk mitigation agency formed by the government, namely the $\mathrm{P} 2 \mathrm{H}$ Center, was found to function in many vital areas of mitigating deforestation risk. Their activities include (i) the formulation of technical policies, plans, programs, and activities for managing revolving funds to finance plantation forest development and environmental investment; (ii) implementing technical policies for revolving fund management to finance plantation 
forest development and environmental investment; (iii) the analysis of the feasibility of revolving fund financing, engagement, and risk control for revolving fund financing; and (iv) the implementation of central administrative and household affairs. In particular, the P2H Center is involved in channeling financing to prevent forest destruction through two main financing business models, namely forestry business financing and environmental investment financing. Out of these two models and related $\mathrm{P} 2 \mathrm{H}$ products, the community's most considerable interest is in the distribution of community forest financing (HR), which has occupied the first level of financial or credit products from $\mathrm{P} 2 \mathrm{H}$ distributed to the community. The delivery of community forest financing is involved with the provision of loans to forest farmers. The community forest farmers obtain this loan by providing collateral for their trees to the P2H Center.

The previous literature on the carbon credit risk mitigation of deforestation and the sustainability literature reveal the importance of all stakeholders, including the businesses and local community, to conduct their business and other livelihood activities for the long term by finding a balance in their economic, social, and environmental interests (Alt et al., 2015; Arafah et al., 2018; Galbreath \& Shum, 2012; Nugroho et al., 2017; Wolf, 2014). This study's findings provide a new contribution these streams of literature as there has been no prior research related to mitigating the risk of forest damage by employing government-initiated $\mathrm{P} 2 \mathrm{H}$ products, such as the distribution of loans, aiming to reduce and prevent forest destruction, particularly in the Indonesian context. Thus, this study analyzed and demonstrated the usefulness as well as the difficulties of implementing $\mathrm{P} 2 \mathrm{H}$ products and services for micro-businesses and local communities engaged in small-scale farming as a carbon risk mitigation of deforestation strategy in emerging economies.

The study also contributes to the carbon credit risk mitigation policy and practice concerning deforestation as it highlights a few key areas that require the government's further attention. First, its findings implicate that in order to obtain better results, the government needs to empower and provide more power and authority to the regulated government agencies responsible for the risk mitigation of deforestation, such as the P2H Center. Then, these agencies can implement more innovative and user-friendly $\mathrm{P} 2 \mathrm{H}$ products and services for their local community stakeholders who engage in forest-damaging business activities. Second, its findings reveal that there was a low level of loan disbursement for the community forest-based loans $(\mathrm{Hkm})$ due to the constraints faced by farmers in the arable land that produces seasonal crops. These farmers thus seem to generate small added value from their input, post-harvest, and marketing. Therefore, special attention and a program are needed from the side of the government and the $\mathrm{P} 2 \mathrm{H}$ Center for these farmers and $\mathrm{Hkm}$ products so as to push them away from environmentally damaging economic activities. Overall, the study's findings indicate that the forest destruction, particularly in Indonesia, mainly occurs as a result of illegal logging by local communities living near forest areas, still needs to be tackled by increasing the public's knowledge on the sustainability impacts of deforestation and also by increasing public welfare, alternative livelihoods, and micro-level business activities through improved access to government financing programs.

These findings also stress the need to conduct future studies on this topic, in particular to explore the multiple views of key stakeholders, including P2H officials, community members, and micro-business owners who engage with the carbon credit risk mitigation activities in forest areas. These studies would require qualitative methodological approaches with the support of surveys or interview methods and broader theoretical frameworks, such as stakeholder theory, to interpret their findings. Also, there is an opportunity for conducting comparative studies on the topic of the carbon credit risk mitigation of deforestation and particularly in cross-country and regional settings. Such studies can illustrate the diverse approaches adopted by various governmental and non-governmental organizations involved with the carbon credit risk mitigation of deforestation and create a critical knowledge base for future research and policy development.

\section{References}

Alam, M. M., Murad, M. W., Noman, A. H. M., \& Ozturk, I. (2016). Relationships among carbon emissions, economic growth, energy consumption and population growth: Testing Environmental Kuznets Curve hypothesis for Brazil, China, India and Indonesia. Ecological Indicators, 70, 466-479. https://doi.org/10.1016/j.ecolind.2016.06.043

Alt, E., Díez-de-Castro, E. P., \& Lloréns-Montes, F. J. (2015). Linking Employee Stakeholders to Environmental Performance: The Role of Proactive Environmental Strategies and Shared Vision. Journal of Business Ethics, 128(1), 167-181. https://doi.org/10.1007/s10551-014-2095-x

Alviya, I., Salaka, F. J., Muttaqin, M. Z., Nurfatriani, F., \& Suryandar, E. Y. (2020). The Effectiveness of Financing Policy for the Developing. Jurnal Analisis Kebijakan Kehutanan, 17(1), 53-73. 
https://doi.org/10.20886/jakk.2020.17.1

Arafah, W., Nugroho, L., Takaya, R., \& Soekapdjo, S. (2018). Marketing Strategy for Renewable Energy development In Indonesia Context Today. International Journal of Energy Economics and Policy, 8(5), 181-186.

Ardhana, I. P. G. (2010). Konservasi Keanekaragaman Hayati Pada Kegiatan Pertambangan Di Kawasan Hutan Di Indonesia. Jurnal Ilmu Pertanian Indonesia, 15(2), 71-77.

Arruda Filho, N. de P., Hino, M. C., \& Beuter, B. P. (2019). Including SDGs in the education of globally responsible leaders. International Journal of Sustainability in Higher Education, 20(5), 856-870. https://doi.org/10.1108/IJSHE-01-2019-0032

Baransano, H. K., \& Mangimbulude, J. C. (2011). Eksploitasi dan Konservasi Sumberdaya Hayati Laut dan Pesisir di Indonesia. Jurnal Biologi Papua, 3(1), 39-45. https://doi.org/10.31957/JBP.547

Barkemeyer, R. (2009). Beyond compliance - below expectations ? CSR in the context of international development. Business Ethics: A European Review, 18(3), 273-289.

Barlow, J., \& Peres, C. A. (2004). Ecological responses to El Niño-induced surface fires in central Brazilian Amazonia: Management implications for flammable tropical forests. Philosophical Transactions of the Royal Society B: Biological Sciences, 359(1443), 367-380. https://doi.org/10.1098/rstb.2003.1423

Beisland, L. A., \& Mersland, R. (2012, July). he Use Of Microfinance Services Among Economically Active Disabled People: Evidence From Uganda. Journal of International Development, 24, 69-83. https://doi.org/10.1002/jid

Carlson, K. M., Curran, L. M., Ratnasari, D., Pittman, A. M., Soares-Filho, B. S., Asner, G. P., ... Rodrigues, H. O. (2012). Committed carbon emissions, deforestation, and community land conversion from oil palm plantation expansion in West Kalimantan, Indonesia. In Proceedings of the National Academy of Sciences of the United States of America (Vol. 109, pp. 7559-7564). https://doi.org/10.1073/pnas.1200452109

Ciais, P., Gasser, T., Paris, J. D., Caldeira, K., Raupach, M. R., Canadell, J. G., ... Gitz, V. (2013). Attributing the increase in atmospheric $\mathrm{CO} 2$ to emitters and absorbers. Nature Climate Change, 3(10), 926-930. https://doi.org/10.1038/nclimate1942

Damayatanti, P. T. (2011). Upaya Pelestarian Hutan Melalui Pengelolaan Sumber-Daya Hutan Bersama Masyarakat. Jurnal Komunitas, 3(1), 70-82.

Donny, J. (2017). Hutan Rakyat dan Hutan Tanaman Rakyat Tidak Sama. Retrieved August 21, 2020, from https://www.borneonews.co.id/berita/55407-hutan-rakyat-dan-hutan-tanaman-rakyat-tidak-sama

Eaton, S., \& Kostka, G. (2014). Authoritarian environmentalism undermined? local leaders' time horizons and environmental policy implementation in China. China Quarterly, 218(1), 359-380. https://doi.org/10.1017/S0305741014000356

Elkinjton, J. (1998). Partnerships from cannibals with forks: The triple bottom line of 21st-century business. Environmental Quality Management, 8(1), 37-51.

Fuller, D. O. (2006). Tropical forest monitoring and remote sensing: A new era of transparency in forest governance?. Singapore Journal of Tropical Geography, 27(1), 15-29. https://doi.org/10.1111/j.1467-9493.2006.00237.x

Galbreath, J., \& Shum, P. (2012). Do customer satisfaction and reputation mediate the CSR-FP link? Evidence from Australia. Australian Journal of Management, 37(2), 211-229. https://doi.org/10.1177/0312896211432941

Ginoga, K., Lugina, M., \& Djaenudin, D. (2005). Policy Analysis of Protection Forest Management. Jurnal Penelitian Sosial \& Ekonomi, 2(2), 203-231.

Goulden, M. L., Miller, S. D., da Rocha, H. R., Menton, M. C., de Freitas, H. C., e Silva Figueira, A. M., \& de Sousa, C. A. D. (2004). Diel and seasonal patterns of tropical forest CO2 exchange. Ecological Applications, 14(4), 42-54. https://doi.org/10.1890/02-6008

Hadi, D. W. (2017). KLHK Dukung Rp. 442 Miliar untuk Petani Hutan - Kementerian LHK. Retrieved December 28, 2020, from https://www.menlhk.go.id/site/single_post/261/klhk-dukung-rp-442-miliar-untuk-petani-hutan

Hakim, I. (2009). The Study o f Financing for Industrial Plantation Forest. Penelitian Sosial Dan Ekonomi Kehutanan, 6(2), 135-158. 
Helmsing, A. H. J. (2003). Local economic development: New generations of actors, policies and instruments for Africa. Public Administration and Development, 23(1), 67-76. https://doi.org/10.1002/pad.260

Hudon, M. (2013). The Ethical Crisis in Microfinance: Issues, Findings, and Implications. Business Ethics Quarterly, 23(4), 561-589.

Kelman, I. (2017). Linking disaster risk reduction, climate change, and the sustainable development goals. Disaster Prevention and Management, 26(3), 254-258. https://doi.org/10.1108/DPM-02-2017-0043

Kusnandar, V. B., \& Widowati, H. (2019). Inilah Deforestasi di Indonesia Periode 1990-2017 | Databoks. Retrieved August 17, 2020, from https://databoks.katadata.co.id/datapublish/2019/08/20/inilah-deforestasi-di-indonesia-periode-1990-2017\#

Leonard, L. (2019). Tunda Waktu Tebang Pohon, KLHK Salurkan Pinjaman untuk Petani Hutan - Ekonomi Bisnis.com. Retrieved August 21, 2020, from https://ekonomi.bisnis.com/read/20190816/99/1137555/tunda-waktu-tebang-pohon-klhk-salurkan-pinjaman-un tuk-petani-hutan

Majid, I., Al Muhdar, M. H. I., Rohman, F., \& Syamsuri, I. (2016). Konservasi Hutan Mangrove Di Pesisir Pantai Kota Ternate Terintegrasi Dengan Kurikulum Sekolah. Bioedukasi Universitas Khairun, 4(2).

Major, D. C., Lehmann, M., \& Fitton, J. (2018). Linking the management of climate change adaptation in small coastal towns and cities to the Sustainable Development Goals. Ocean and Coastal Management, 163(December 2017), 205-208. https://doi.org/10.1016/j.ocecoaman.2018.06.010

Mando, L. O. A. S., Kandari, A. M., Kahirun, Rosmarlinasiah, Kasim, S., Midi, L. O., .. Mardhatillah, S. (2020). Level of Management Participation and Financial Analysis of The Community Forest With a Logging Delay System In The South Konawe Regency. Jurnal Belantara, 3(2), 128-138.

Maryati, T. (2011). Preferensi Masyarakat Terhadap Pemilihan Jenis Pohon Dalam Pengelolaan Hutan Berbasis Masyarakat. Jurnal Hutan Tropis, 12(31), 123-131.

Meijaard, E., Abram, N. K., Wells, J. A., Pellier, A. S., Ancrenaz, M., Gaveau, D. L. A., .. Mengersen, K. (2013). People's Perceptions about the Importance of Forests on Borneo. PLoS ONE, 8(9). https://doi.org/10.1371/journal.pone.0073008

Millward-hopkins, J., \& Purnell, P. (2019). Circulating blame in the circular economy: The case of wood-waste biofuels and coal ash. Energy Policy, 129(November 2018), 168-172. https://doi.org/10.1016/j.enpol.2019.02.019

Mustofa, M. S. (2011). Perilaku Masyarakat Desa Hutan Dalam Memanfaatkan Lahan di Bawah Tegakan. Jurnal Kompetensi, 3(1), 1-11.

Nandini, R. (2013). Evaluasi Pengelolaan Hutan Kemasyarakatan (HKm) Pada Hutan Produksidan Hutan Lindung di Pulau Lombok. Jurnal Penelitian Hutan Tanaman, 10(1), 43-55. https://doi.org/10.20886/jpht.2013.10.1.43-55

Nilsen, H. R. (2019). The hierarchy of resource use for a sustainable circular economy. International Journal of Social Economics, 47(1), 27-40. https://doi.org/10.1108/IJSE-02-2019-0103

Nivette, A. E., \& Akoensi, T. D. (2019). Determinants of satisfaction with police in a developing country: a randomised vignette study. An International Journal of Research and Policy, 29(4), 471-487. https://doi.org/10.1080/10439463.2017.1380643

Nugroho, B. (2010). Institutional Development for Community Forest Revolving Fund. Jurnal Manajemen Hutan Tropika, XVI(3), 118-125.

Nugroho, L., Badawi, A., \& Hidayah, N. (2019). Discourses of Sustainable Finance Implementation in Islamic Bank ( Cases Studies in Bank Mandiri Syariah 2018 ). International Journal of Financial Research, 10(6), 108-117. https://doi.org/10.5430/ijfr.v10n6p108

Nugroho, L., Nugraha, E., \& Badawi, A. (2020). Sustainable Finance Portfolio Analysis in Islamic Bank (Segment Perspective). International Journal of Commerce and Finance, 6(2), 226-240.

Nugroho, L., Utami, W., Akbar, T., \& Arafah, W. (2017). The challenges of microfinance institutions in empowering micro and small entrepreneur to implementating green activity. International Journal of Energy Economics and Policy, 7(3).

Onwuegbuzie, A. J., \& Frels, R. K. (2015). Using Q Methodology in the Literature Review Process: A Mixed 
Research Approach. Journal of Educational Issues, 1(2), 90. https://doi.org/10.5296/jei.v1i2.8396

P2H-Center. (2015). P2H Central Business Strategy Plan. Jakarta.

P2H-Center. (2018). P2H Performance Review 2018. Jakarta. Retrieved from http://library1.nida.ac.th/termpaper6/sd/2554/19755.pdf

P2H-Center. (2019a). Flyer about P2H Center. Jakarta.

P2H-Center. (2019b). Products of P2H. Jakarta.

P2H-Center. (2019c). Skema Bagi Hasil. Jakarta.

P2H-Center. (2020a). Sejarah - BLU Pusat P2H. Retrieved December 28, 2020, from https://blup3h.id/sejarah/

P2H-Center. (2020b). Visi Misi - BLU Pusat P2H. Retrieved December 28, 2020, from https://blup3h.id/tentang-blu-pusat-p2h/visi-misi/

Pieroni, M. P. P., Mcaloone, T. C., \& Pigosso, D. C. A. (2019, January). Business model innovation for circular economy and sustainability: A review of approaches. Journal of Celeaner Production, 215, 198-216. https://doi.org/10.1016/j.jclepro.2019.01.036

Polozhentseva, Y., \& Klevtsova, M. (2015). Instruments of Development of Cluster Policy: Stages, Models, International Practice. In Procedia Economics and Finance (Vol. 27, pp. 529-537). Elsevier B.V. https://doi.org/10.1016/s2212-5671(15)01029-1

Postelnicu, L., \& Hermes, N. (2018). Microfinance Performance and Social Capital: A Cross-Country Analysis. Journal of Business Ethics, 153(2), 427-445. https://doi.org/10.1007/s10551-016-3326-0

Raharjo, A. I. (2019). KLHK Dorong Usaha Kehutanan Off Farm Manfaatkan Fasilitas Dana Bergulir - Nasional JPNN.com. Retrieved August 21, 2020, from https://www.jpnn.com/news/klhk-dorong-usaha-kehutanan-off-farm-manfaatkan-fasilitas-dana-bergulir

Safitri, I. D. A., Roessali, W., \& Ekowati, T. (2019). Analisis Pendapatan Usaha Penggemukan Sapi Potong Yang Mendapat Dukungan Kredit Tunda Tebang (KTT) Di Kabupaten Semarang. JSEP (Journal of Social and Agricultural Economics), 12(2), 17. https://doi.org/10.19184/jsep.v12i2.11465

Sanudin, S., Sadono, R., \& Purwanto, R. (2015). Implementation of Community Timber Plantation in Pesisir Barat District-Lampung and Tebo District-Jambi. Jurnal Manusia Dan Lingkungan, 22(3), 341-349. Retrieved from https://journal.ugm.ac.id/JML/article/view/18760

Sapkota, A., Symons, J. M., Kleissl, J., Wang, L., Parlange, M. B., Ondov, J., ... Buckley, T. J. (2005). Impact of the 2002 Canadian forest fires on particulate matter air quality in Baltimore City. Environmental Science and Technology, 39(1), 24-32. https://doi.org/10.1021/es035311z

Scheyvens, R., Banks, G., \& Hughes, E. (2016). The Private Sector and the SDGs: The Need to Move Beyond 'Business as Usual.' Sustainable Development, 24(6), 371-382. https://doi.org/10.1002/sd.1623

Scott, C. (2009). Governing Without Law or Governing Without Government? New-ish Governance and the Legitimacy of the EU. European Law Journal, 15(2), 160-173.

Skogstad, G. (2003). Who Governs? Who Should Govern?: Political Authority and Legitimacy in Canada in the Twenty-First Century. Canadian Journal of Political Science, 36(5), 955-973.

Slaper, T. F., \& Hall, T. J. (2011). The Triple Bottom Line: What Is It and How Does It Work? Indiana Business Review, 86(1), 4-8.

Sovacool, B. K., Linnér, B. O., \& Klein, R. J. T. (2017). Climate change adaptation and the Least Developed Countries Fund (LDCF): Qualitative insights from policy implementation in the Asia-Pacific. Climatic Change, 140(2), 209-226. https://doi.org/10.1007/s10584-016-1839-2

Stupak, I., Asikainen, A., Jonsell, M., Karltun, E., Lunnan, A., Mizaraite, D., ... Tamminen, P. (2007). Sustainable utilisation of forest biomass for energy-Possibilities and problems: Policy, legislation, certification, and recommendations and guidelines in the Nordic, Baltic, and other European countries. Biomass and Bioenergy, 31(10), 666-684. https://doi.org/10.1016/j.biombioe.2007.06.012

Suri, R. S., Nesrallah, G. E., Mainra, R., Garg, A. X., Lindsay, R. M., Greene, T., \& Daugirdas, J. T. (2006). Daily hemodialysis: a systematic review. Clinical Journal of the American Society of Nephrology: CJASN, 1(1), 33-42. https://doi.org/10.2215/CJN.00340705 
Tupan, C. I., \& Lailossa, G. W. (2019). Potential of stock carbon in mangrove Sonneratia alba in Passo coastal waters, Inner Ambon Bay. In IOP Conference Series: Earth and Environmental Science (Vol. 339, pp. 1-7). https://doi.org/10.1088/1755-1315/339/1/012009

Utami, W., Nugroho, L., Mappanyuki, R., \& Yelvionita, V. (2020). Early Warning Fraud Determinants In Banking Industries. Asian Economic and Financial Review, 10(6), 604-627. https://doi.org/10.18488/journal.aefr.2020.106.604.627

Weintraum, B. (1983). Freezing the Debtor's Account: A Banker's Dilemma Under the Bankruptcy Code. Banking $L J, 100$.

Welford, R., Ytterhus, B., \& Eligh, J. (1999). Tourism and sustainable development: An analysis of policy and guidelines for managing provision and consumption. Sustainable Development, 7(4), 165-177. https://doi.org/10.1002/(SICI)1099-1719(199911)7:4<165::AID-SD117>3.0.CO;2-F

Wolf, J. (2014). The Relationship Between Sustainable Supply Chain Management, Stakeholder Pressure and Corporate Sustainability Performance. Journal of Business Ethics, 119(3), 317-328. https://doi.org/10.1007/s10551-012-1603-0

\section{Copyrights}

Copyright for this article is retained by the author(s), with first publication rights granted to the journal.

This is an open-access article distributed under the terms and conditions of the Creative Commons Attribution license (http://creativecommons.org/licenses/by/4.0/). 